\title{
Effect of high fibre food mix on lipid profile and body weight in obese subjects.
}

\author{
Geetha K, Geetha Yankanchi M*, Netravati Hiremath
}

Department of Foods and Nutrition, All India Coordinated Research Project on Home Science, University of Agricultural Sciences, GKVK, India

\begin{abstract}
The study aimed to assess the efficacy of developed high fibre food mix on the management of obesity. The high fibre food mix was developed by using region specific ingredients. The dietary intervention was carried out on obese rural farm women for a period of 120 days by providing $1 / 3$ rd daily requirement of protein and energy. Impact of food mix was evaluated by assessing somatic and biochemical parameters at pre and post dietary intervention. The developed mix contained protein $(15.80 \pm 0.32 \mathrm{~g})$, fat $(2.60 \pm 0.12 \mathrm{~g})$, energy $(320 \mathrm{kcal})$, carbohydrate $(60.75 \mathrm{~g})$ and dietary fibre $(29.5 \pm 0.91 \mathrm{~g})$ per $100 \mathrm{~g}$ of the mix. Significant reduction in weight $(65.34 \pm 10.97 \mathrm{~kg}$ to $63.23 \pm 10.60 \mathrm{~kg})$ leading to reduction in body mass index $(27.84 \pm 4.14$ to $26.95 \pm 4.06)$ and reduction in hip circumference $(105.23 \pm 9.96 \mathrm{~cm}$ to $104.93 \pm 9.90 \mathrm{~cm})$ was recorded at $\mathbf{P} \leq \mathbf{0 . 0 5}$ level. Significant decrease in cholesterol, low density lipoprotein and fasting blood sugar was observed from pre to post test. The food based dietary intervention with high protein and dietary fibre showed desirable effects on body weight and biochemical parameters. Hence the inclusion of millets, legumes vegetables and oilseeds in the daily diet enhances the dietary fibre intake and thus helps in management of body weight.
\end{abstract}

Keywords: Obesity, Dietary intervention, Dietary fibre, Body mass index, Lipid profile.

Accepted on May 24, 2019

\section{Introduction}

Obesity is one of the risk factors for morbidity and mortality including type 2 diabetes, cardiovascular, osteoarthritis, malignant and metabolic diseases. The imbalance between energy intake and expenditure is the main cause of overweight and obesity. Obesity is defined as weight $>20$ per cent above the ideal weight. Body Mass Index (BMI) is an anthropometric index which is calculated by person's weight in kilograms divided by the square of his height in meters $\left(\mathrm{kg} / \mathrm{m}^{2}\right)$ for classifying subjects as overweight and obesity. Person having BMI value 23 to 24.99 are overweight and 25 and above as obese [1]. Approximately 1.5 billion adults are overweight or obese around the world and obesity is being concerned as a global epidemic [2]. Since nineties there has been an increase in over nutrition among women in India [3]. Data from NFHS-4 indicated that around 20.70 per cent of women are over nourished [4]. In India, the increased levels of obesity are primarily associated with the transformation from rural to urban lifestyle. Modern lifestyle associated with easy access to food, lack of exercise, sedentary lifestyle, calorie dense foods and excessive television viewing contribute to the development of non-communicable diseases. Dietary fibre being one of the essential components of the healthy diet has gained the important physiological and metabolic functions. The properties of fibre make the protective role in management of overweight and obesity. Considering the importance of dietary fibre rich foods, the present study was undertaken to develop and evaluate the efficacy of high fibre food mix for management of overweight and obesity among rural farm women.

\section{Materials and Methods}

\section{Development of millet based mix}

Millet based high fibre food mix was prepared by using the ingredients viz., finger millet (Eleusine coracana), little millet (Panicum sumatrense), defatted soya (Glycine max) flour, whole green gram (Vigna radiata), fenugreek seeds (Trigonella foenum-graecum), cluster bean (Cyamopsis tetragonoloba), drumstick leaves (Moringa oleifera) and curry leaves (Murraya koinigii ). All the ingredients used for the preparation of mix were procured from local market of Bengaluru. Fresh cluster bean, drumstick leaves and curry leaves were washed thoroughly, blanched for one minute and oven dried and made into flour. Further finger millet, little millet, whole green gram and fenugreek seeds were cleaned and made into flour. Millet based mix was prepared by mixing all the flours and kept airtight for further nutrient analysis and preparation of the product for use. 


\section{Nutrient analysis}

Proximate composition of developed mix was analyzed by using standard Association of Official Analytical Chemists (AOAC) protocol. Further, carbohydrate content was calculated by differential method and calorific value was obtained by multiplying the carbohydrate and protein content by four and fat by nine $\mathrm{k}$ cal. Dietary fibre was analyzed by AOAC method by using Fibra plus instrument and micronutrients viz., iron and calcium were analyzed by atomic absorption spectrometry [5].

\section{Selection of subjects}

Randomly 240 women involved in farm activity from seven villages of Bengaluru north taluk were screened to select the overweight and obese subjects. Height, weight, waist circumference (WC) and hip circumference (HC) were the body measurements measured for the all the subjects. BMI was derived based on height and weight. Based on BMI the subjects were classified as underweight, normal, overweight and obese. Among the screened subjects a total of 60 subjects having $\mathrm{BMI}>22.99$ were selected and divided into two groups (Experimental 30 and Control 30). A written consent was obtained from all the selected subjects for their willingness to participate in the dietary intervention. Blood samples of the selected subjects were drawn by a trained technician under the medical supervision and analyzed for lipid profile and Fasting Blood Sugar (FBS) under clinical setting prior to the initiation of the study.

\section{Dietary intervention}

Dietary intervention was carried out for a period of 120 days on rural obese women involved in farm activities. For experimental group $(n=30)$, dumpling prepared from the developed high fibre food mix was given for lunch along with curry. The quantity of high fibre food mix used for the preparation of dumpling was fixed based on their average ideal body weight. The recommended dietary allowances to meet $1 / 3$ rd of their daily requirement for energy and protein were taken care while fixing the quantity of food mix. The subjects in experimental group were monitored throughout the intervention period to ensure the consumption of provided food. Further one to one counseling on foods to be included and excluded in their diet other than the food served was given to the experimental group. Audio visual aids, method demonstrations were used for group counseling. The control group $(n=30)$ was kept neutral without any dietary intervention and counseling. Somatic and biochemical parameters were measured in both experimental and control group at pre and post level.

The data obtained was statistically analyzed. Mean and standard deviation were calculated for each studied variable. Significance level was assessed through paired " $t$ " test in both experimental and control group.

\section{Results}

The nutrient composition of millet-based mix is presented in Table 1. The developed food mix contains $9.10 \pm 0.07 \mathrm{~g}$ of moisture, $15.00 \pm 0.32 \mathrm{~g}$ of protein, $2.60 \pm 0.12 \mathrm{~g}$ of fat, 60.75 $\mathrm{g}$ of carbohydrate, $320 \mathrm{kcal}$ energy, $3.40 \pm 0.18 \mathrm{~g}$ of ash, $9.11 \pm$ $0.83 \mathrm{~g}$ of crude fibre and dietary fibre $29.50 \pm 0.91 \mathrm{~g}$ per $100 \mathrm{~g}$. Iron and calcium was found to be $8.33 \pm 0.12$ and $366 \pm 0.08$ $\mathrm{mg}$ per $100 \mathrm{~g}$ respectively. The developed mix contains noticeably good amount of protein, low amount of fat, energy and high amount of dietary fibre and minerals.

The mean height, weight, BMI, waist circumference, hip circumference of experimental and control subject's pre and post intervention period is presented in Table 2. The mean weight of subjects in experimental group decreased from 65.34 $\pm 10.97 \mathrm{~kg}$ to $63.23 \pm 10.60 \mathrm{~kg}$. The decrease in weight was found to be highly significant $(\mathrm{p}=0.01 \%)$. Similarly, significant reduction in BMI of subjects in experimental group was observed $(27.84 \pm 4.14$ to $26.95 \pm 4.06)$ at $p=0.01$ per cent. In contrary the mean weight of the subjects in control group increased from 62.30 to $63.09 \mathrm{~kg}$ with concurrent increase in BMI, however, the increment was non-significant. In experimental group the mean WC and HC decreased from $88.43 \mathrm{~cm}$ to $88.20 \mathrm{~cm}$ and 105.23 to $104.93 \mathrm{~cm}$ respectively and the reduction in $\mathrm{HC}$ was found to be significant $(\mathrm{p}=0.05 \%)$. In control group the $\mathrm{WC}$ and $\mathrm{HC}$ were increased from $87.06 \mathrm{~cm}$ to $87.63 \mathrm{~cm}$ and $104.46 \mathrm{~cm}$ to $105 \mathrm{~cm}$ respectively, however, difference was non-significant.

Table 1. Nutrient composition of high fibre food mix (100 g).

\begin{tabular}{ll}
\hline \multicolumn{1}{c}{ Nutrients } & \multicolumn{1}{c}{ Quantity } \\
\hline Moisture $(\mathrm{g})$ & $9.10 \pm 0.07$ \\
\hline Protein $(\mathrm{g})$ & $15.00 \pm 0.32$ \\
\hline Fat $(\mathrm{g})$ & $2.60 \pm 0.12$ \\
\hline Total Carbohydrates $(\mathrm{g})^{*}$ & 60.75 \\
\hline Energy (k cal) ${ }^{*}$ & 320 \\
\hline Ash (g) & $3.40 \pm 0.18$ \\
\hline Crude fibre (g) & $9.11 \pm 0.83$ \\
\hline Dietary fiber (g) & $29.50 \pm 0.91$ \\
\hline Iron (mg) & $8.33 \pm 0.12$ \\
\hline Calcium(mg) & $366 \pm 0.08$ \\
\hline${ }^{*}$ Calculated values. & \\
\hline
\end{tabular}

The detailed information on the changes in the biochemical parameters that occurred in the subjects after 120 days of dietary intervention in comparison with control subject is presented in Table 3. It is evident from the table that there is statistically significant reduction in the total cholesterol, LDL, and FBS among experimental group. However, the triglyceride and VLDL showed a decrease from initial to final which was statistically not significant. Among the control subjects some of the parameters namely total cholesterol, HDL, LDL showed 
decrease from initial to final which was statistically nonsignificant. Similarly, there was increase in triglyceride and VLDL which was also non-significant. There was a significant decrease in FBS level from initial too final among the experimental group which was not so among the control group.

Table 2. Impact of food based dietary intervention on anthropometric parameters.

\begin{tabular}{|c|c|c|c|c|c|c|}
\hline \multirow{2}{*}{$\begin{array}{c}\text { Anthropometric } \\
\text { measurements }\end{array}$} & \multicolumn{3}{|c|}{ Experimental group $(n=30)$} & \multicolumn{3}{|c|}{ Control group(n=30) } \\
\hline & Pre & Post & 't' value & Pre & Post & 't' value \\
\hline Height (cm) & $153.07 \pm 4.53$ & - & - & $153.03 \pm 6.57$ & - & - \\
\hline Weight (kg) & $65.34 \pm 10.97$ & $63.23 \pm 10.60$ & $10.56^{\star \star}$ & $62.30 \pm 9.13$ & $63.09 \pm 9.23$ & $-3.34 \mathrm{~ns}$ \\
\hline BMI & $27.84 \pm 4.14$ & $26.95 \pm 4.06$ & $11.27^{\star \star}$ & $26.57 \pm 3.30$ & $26.91 \pm 3.29$ & $-3.41 \mathrm{~ns}$ \\
\hline WC $(\mathrm{cm})$ & $88.43 \pm 9.57$ & $88.20 \pm 9.50$ & $1.36^{\mathrm{ns}}$ & $87.06 \pm 9.02$ & $87.63 \pm 9.42$ & $-3.32 n s$ \\
\hline $\mathrm{HC}(\mathrm{cm})$ & $105.23 \pm 9.96$ & $104.93 \pm 9.90$ & $2.52^{*}$ & $104.46 \pm 6.70$ & $105.00 \pm 6.78$ & $-4.0 \mathrm{~ns}$ \\
\hline WHR & $0.84 \pm 0.05$ & $0.84 \pm 0.05$ & $0.10^{\mathrm{ns}}$ & $0.88 \pm 0.10$ & $0.88 \pm 0.11$ & $-0.52 \mathrm{~ns}$ \\
\hline
\end{tabular}

** Significant at 0.01 level; "Significant at 0.05 level and ns: Non-Significant Note. WC: Waist circumference; HC: Hip Circumference

Table 3 Impact of food based dietary intervention on biochemical parameters.

\begin{tabular}{|c|c|c|c|c|c|c|}
\hline \multirow{2}{*}{ Clinical measures } & \multicolumn{3}{|c|}{ Experimental group $(n=30)$} & \multicolumn{3}{|c|}{ Control group $(n=30)$} \\
\hline & Pre & Post & 't' value & Pre & Post & 't' value \\
\hline Cholesterol(mg/dl) & $187.87 \pm 33.90$ & $165.63 \pm 27.33$ & $6.36^{* *}$ & $176.30 \pm 26.04$ & $169.33 \pm 36.90$ & $1.92 \mathrm{~ns}$ \\
\hline TGL (mg/dl) & $174.83 \pm 85.94$ & $173.87 \pm 65.89$ & $0.08^{\mathrm{ns}}$ & $148.26 \pm 57.75$ & $149.9 \pm 57.05$ & $-0.17 \mathrm{~ns}$ \\
\hline $\mathrm{HDL}(\mathrm{mg} / \mathrm{dl})$ & $42.57 \pm 4.17$ & $40.67 \pm 4.23$ & $2.01^{\mathrm{ns}}$ & $42.80 \pm 4.90$ & $41.46 \pm 4.26$ & $1.87 \mathrm{~ns}$ \\
\hline LDL (mg/dl) & $110.57 \pm 25.96$ & $94.03 \pm 22.14$ & $5.05^{\star *}$ & $105.1 \pm 20.94$ & $98.96 \pm 28.43$ & $1.90 \mathrm{~ns}$ \\
\hline VLDL (mg/dl) & $34.97 \pm 17.19$ & $34.77 \pm 13.18$ & $0.083^{\text {ns }}$ & $29.65 \pm 11.55$ & $29.98 \pm 15.01$ & $-0.17 \mathrm{~ns}$ \\
\hline Chol/HDL & $4.43 \pm 0.77$ & $4.07 \pm 0.55$ & $2.93^{* *}$ & $4.13 \pm 0.49$ & $4.09 \pm 0.80$ & $0.35 \mathrm{~ns}$ \\
\hline LDL/HDL & $2.64 \pm 0.62$ & $2.26 \pm 0.55$ & $3.67^{\star \star}$ & $2.48 \pm 0.47$ & $2.27 \pm 0.63$ & $2.02 \mathrm{~ns}$ \\
\hline FBS (mg/dl) & $120.50 \pm 53.56$ & $102.87 \pm 46.85$ & $4.89^{* *}$ & $176.30 \pm 26.04$ & $169.33 \pm 36.90$ & $1.72 \mathrm{~ns}$ \\
\hline
\end{tabular}

*Significant at 0.05 level; ns: Non-Significant, HDL: High Density Lipoprotein, LDL: Low Density Lipoprotein, VLDL: Very Low-Density Lipoprotein, FBS: Fasting Blood Sugar

\section{Discussion}

In the present study the developed food mix was higher in terms of protein and dietary fibre compared to the millet based composite food mix where the protein content ranged from 10.21 to 13.42 per cent and dietary fibre ranging from 20.60 to 23.4 per cent [6]. Reported result on composite flour mix developed from millets and legumes also had lower protein (10.8 to $11.15 \mathrm{~g} / 100 \mathrm{~g})$ and fat content $(0.67$ to $1.44 \mathrm{~g} / 100 \mathrm{~g})$ compared to the mix developed under the study [7]. The use of soya bean and green gram in addition to millets are the contributing factors for higher protein content. Incorporation of vegetables and fenugreek seeds in addition to whole grains increased the dietary fibre content. Several epidemiological studies showed an inverse relationship between dietary fibre intake and weight loss [8]. An inverse correlation between whole grain ingestion and change in body weight of middleaged women [9]. Fibres have the ability to displace the energy from other nutrients by adding bulk and weight to the meal.
Thus, increasing the satiety and decreasing the intake. Many studies have shown that low fat, high protein diets may increase weight loss body fat mass loss satiety and mitigate reduction in fat free mass and resting energy expenditure [10-12]. In the present study the mix with low fat, moderate protein and high dietary fibre with certain modification in their meal pattern would be the contributory factor for reduction in somatic measurements among the experimental group compared to control. It has been reported that the consumption of both soluble and insoluble dietary fibre increase satiety there by decrease the intake of quantity of food which is also evident from the present study. Decrease in energy density by 10 per cent and weight loss of $1.9 \mathrm{~kg}$ over 3.8 months resulted from consumption of additional fibre $14 \mathrm{~g}$ /day [13]. Similarly, in the present study the food contained $29.5 \mathrm{~g}$ of fibre with low fat per meal provided in the intervention. This might be the one of the causes for reduction in the weight of the subjects in experimental group. The finding of the changes in biochemical parameters of the present study is in line with findings of other 
researchers [14-17]. Further, the lowering effect of millet based dietary fibre on plasma lipid concentration and FBS was observed in low glycemic index diet of lower fat content [18].

\section{Conclusion}

Transition in lifestyle with more consumption of junk foods and reduced intake of fruits and vegetables coupled with sedentary lifestyle are the main causes for overweight and obesity. This is because most of the junk foods are rich in fat salt, preservatives, simple sugars and less in complex carbohydrates. The intake of fibre in such foods is far behind the recommendation. However, inclusion of millets, legumes and vegetables in the daily diet enhances the dietary fibre intake. This along with modification in lifestyle would benefit in weight reduction which would aids in prevention of secondary complications.

\section{Acknowledgement}

The research team acknowledges the Indian Council of Agricultural Research (ICAR) - Central Institute for Women in Agriculture (CIWA), Government of India and University of Agricultural Sciences, Gandhi Krishi Vigyan Kendra, Bengaluru, Government of Karnataka (GOK) for funding the research.

\section{Ethical Committee Approval}

Institutional ethical committee clearance certificate was obtained prior to the initiation of the intervention study (Proposal No. AICRP FN 2018001 and approved on 10.02.2018).

\section{Conflict of Interest}

There is no conflict of interest.

\section{References:}

1. Lad Hasit D, Vasudha, KC. A study of the levels of urinary microalbumin in non-diabetic normotensive obese individuals. Adv Biol Chem 2012; 2: 171-175.

2. Nguyen T, Lau DC. The obesity epidemic and its impact on hypertension. Can J Cardiol 2012; 28: 326-333.

3. http://rchiips.org/nfhs/nfhs3.shtml.

4. http://rchiips.org/nfhs/factsheet_nfhs-4.shtml

5. Aboagarib AAE, Yang R, Hua X, Azhari S. Chemical compositions, nutritional properties and volatile compounds of Guddaim (Grewia Tenax. Forssk) Siddeeg. 2014; 2 : 187-192.

6. http://krishikosh.egranth.ac.in/handle/1/5810007985.

7. http://krishikosh.egranth.ac.in/bitstream/1/5810006689/1/ Th-9231

8. Koh-Banerjee P, Rimm EB. Whole grain consumption and weight gain: areview of the epidemiological evidence, potential mechanisms and opportunities for future research. Proce Nutr Soc 2003; 62: 25-29.

9. Liu S, Willet WC, Manson JE, Hu FB, Rosner B. Relation between changes in intakes of dietary fibre and grain products and changes in weight development of obesity among middle aged women. Am J Clin Nutr. 2003; 78: 920-927.

10. Flechtne MM, Boehm BO, Wittmann R, Thoma U, Ditschuneit HH. Enhanced weight loss with proteinenriched meal replacementsin subjects with the metabolic syndrome. Diabetes Metab Res Rev 2010; 26: 393-405.

11. Layman DK, Evans EM, Erickson D, Seyler J, Weber J, Bagshaw D, Griel A, Psota T, Kris-Etherton P. A moderateprotein diet produces sustained weight loss andlong-term changes in body composition and blood lipids in obese adults. J Nutr 2009; 139: 514-521.

12. Hochstenbach WA, Veldhorst MAB, NieuwenhuizenAG, Westerterp PMS, Westerterp KR. Comparison of 2 dietswith either $25 \%$ or $10 \%$ of energy as casein on energy expenditure,substrate balance, and appetite profile. Am J Clin Nutr. 2009; 89: 831-838.

13. Howarth NC, Saltzman E, Roberts SB. Dietary fibre and weight regulation. Nutr Rev 2001; 59: 129-139.

14. Ramachadran A. Das AK, Joshi SR, Yajnik CS, Shah S, Prasanna K. Current status of diabetes in India and need for novel therapeutic agents. JAPI 2010; 58: 7-9.

15. Thathola A, Srivastava S, Singh G. Effect of foxtail millet (Setaria italica) supplementation on serum glucose, serum lipids and glycosylated hemoglobin in type 2 diabetes. Diabetol Cro 2011; 40: 23-28.

16. Jarvi AE, Karlstorm BE, Grandfeldt YE, Bjorck IE, Asp $\mathrm{NG}$, Vessby BO. Improved glycemic control and lipid profile and normalized fibrinolytic activity on a lowglycemic index diet in type 2 diabetic patients. Diabetic Care 1999; 22: 8-10.

17. Koul L, Nidhiry J. High-fiber diet in the treatment of obesity and hypercholesterolemia. J Natl Med Assoc 1993; 85: 231-232.

18. Jali MV, Kamatar MY, Jali SM, Hiremath MB Naik RK. Efficacy of value-added foxtail millet therapeutic food in the management of diabetes and dyslipidemia in type 2 diabetic patients. Rec res sci technol 2012; 4: 3-4.

\section{Correspondence to:}

M. Yankanchi

Department of Foods and Nutrition

All India Coordinated Research Project on Home Science

University of Agricultural Sciences

GKVK

India 